\title{
Parent's Position In Developing Children's Nature Implications In ERA 4.0
}

\author{
${ }^{1}$ Agus Yosep Abduloh, ${ }^{2}$ Ahmad Nurwadjah, ${ }^{3}$ Andewi Suhartini, \\ ${ }^{4}$ Hisam Ahyani, ${ }^{5}$ Naeli Mutmainah \\ Program Studi Pendidikan Agama Islam \\ Universitas Islam Negeri Sunan Gunung Djati Bandung, Indonesia \\ Sekolah Tinggi Agama Islam Miftahul Ulum Tasikmalaya, Indonesia \\ Sekolah Tinggi Agama Islam Miftahul Huda Al Azhar Banjar, Indonesia \\ Sekolah Tinggi Ilmu Tarbiyah Nahdhotul Ulama Al-Farabi Pangandaran \\ 1 agusyosepabd01@ gmail.com; ${ }^{2}$ nurwadjah@unsgd.ac.id; ${ }^{3}$ andewi.suhartini@uinsgd.ac.id; \\ ${ }^{4}$ hisamahyani@gmail.com; ${ }^{5}$ naelimutmainah.ney@gmail.com
}

\begin{abstract}
The impact of changing times is so great, such as the 4.0 era as it is today for children, teenagers, and parents, who need to adapt to the current era. And it would be nice for us to provide an overview and understanding to our children in a way that is appropriate for their age in order to be able to grasp what we mean. And we should educate more with tenderness and love, the position of parents in developing children's nature, the implications of which in the 4.0 era are very important because with that we can be closer and easier in providing education. The educational method that we use may be done in realizing a disciplined and independent child's personality which stems from the child's desire to achieve happiness in the world and the hereafter. This research method is library research with the object of the verses of the Qur'an using several interpretations from the commentators including: Tafsir Jalalain Tafsir Ibn Kathir Tafsir Al-Maraghi to uncover and explore the Position of Parents in the Al-Qur'an, Role Parents in Developing Children's Fitrah, and Implications of the Role of Parents in Developing Children's Fitrah in the 4.0 era. The results of the study show that 1) The view of Islamic education regarding the nature of the child means that the position of the child has two opposing sides. One side of the child is the trust of Allah entrusted to the parents. On the other hand, children are nature for the lives of parents in particular and society and the environment in general. 2) The implications of the position of parents in developing children's nature, the implications of which in the 4.0 era are a necessity, as mufassir views and opinions Salaf scholars have different opinions in interpreting the word fitrah, the majority argue that the meaning of fitrah is Islam. So that it has become a joint obligation for parents to maintain the mandate of Allah SWT in the form of children, which in the 4.0 era children must be monitored and supervised to ensure that the child's behavior (behavior) as a child who was born naturally (good) in origin.
\end{abstract}

Keywords: Parents, Children's Fitrah, Implications of Children's Fitrah in Era 4.0

\section{Introduction}

All Today, the problem of morality among young people, especially students and college students, has become a common problem and is a problem for which there is no complete answer. Why are students and students at this time so easily influenced by foreign cultures? Why are students and students easily provoked and easily angered so that there are frequent brawls and clashes between them? why are students and college students involved in the use and distribution of drugs? Why are there so many students and college students who 


\section{Agus Yosep Abduloh, dkk}

are so free to associate with other types, which is indicated by the widespread behavior of free sex, the phenomenon of pregnancy out of wedlock as well as abortion, which are seen as natural things without any sense of sin, discomfort, restlessness and shame? And why do students and students seem to have little respect for their teachers or professors, and even for their own parents? This is a picture of the nation's generation of children who are starting to threaten their personal integrity (split personality) (Alim, 2006, p. 1).

One solution to the above, is through education. The educational process has started since the creation of the first human in the world. Humans have a responsibility to manage the universe so that it can be put to good use. Humans need knowledge and expertise to carry out these management tasks properly. Therefore, they try to learn through the educational process to develop their intellectual potential, talents and creativity. Informal educational activities take place for the first time in the family environment. Parents act as teachers who teach and educate children, so that they have the knowledge and skills needed to carry out a particular job (Dariyo, 2013, pp. 1-3). Educational activities in the family run by parents, then developed by some people into schools, namely an activity that is formal, systematic and structured to be adapted to the demands of community development. Schools have become formal institutions that prepare human children to develop their full potential optimally. In the long term, advanced formal education will make a maximum contribution to improving the welfare and prosperity of a nation.

The objectives of education cover three areas, namely: 1) Individual goals related to individuals, learning (learning) and with their personalities, and what relates these individuals to changes in behavior, activities and achievements and to the desired growth in their personality. 2). Social goals relating to the life of society as a whole, and with matters relating to the desired life change, growth and enrichment of experience and desired progress. 3). Professional goals related to education and teaching as a science, as an art, as a profession and as an activity among the activities of society (Syaibany, 1979, p. 399). The term education in Islam is often expressed in the form of the words tarbiyah, ta'lim, ta'dib and riyadiyah. Each term (word) has a different meaning, because it is caused by the context of the sentence (siyaq al kalam) although in certain cases these terms have the same meaning (Gunawan, 2012, p. 198). Although the word tarbiyah is not specifically found in the Qur'an, however, there are sentences that match the term, such as the sentences rabb, rabbayani, nurabbi, ribbiyun and rabbani. And this form then forms one word, the masdar form (infinitive), namely the word tarbiyah. According to Mu'jam Lughawi (language dictionary) 
the word tarbiyat has three basic root words which all have the same meaning, namely: 1) Rabba-yarbu-tarbiyahan which has an added meaning (zada) and develops (naama) this is based on the Qur'an in the letter Rum [30] verse 39 which means: and something Riba (extra) that you give so that He increases in human wealth, then Riba does not add to the side of Allah. and what you give in the form of zakat which you mean to achieve the pleasure of Allah, then (who do so) Those are the people who multiply (the reward); 2) Rabbi-yurabbitarbiyyatan which means to grow (nasyaa) and become big (tara ra'a) and; 3) Rabba-yuraabitarbiyatan which means to improve (ashlaha) control of affairs, maintain, care for, fulfill, beautify, feed, nurture, master, possess, regulate, preserve and exist (Gunawan, 2012, p. 198).

And it would be nice for us to provide an overview and understanding to our children in a way that is appropriate for their age in order to be able to grasp what we mean. And we should be more educated with gentleness and compassion, because with that we can be closer and easier in providing education. The educational method that we use may be done in realizing a disciplined and independent child's personality which stems from the child's desire to achieve happiness in this world and the hereafter. And also make other people happy who keep the spirit of work to achieve both. This achievement certainly requires effort in achieving it. The involvement of parents in children's activities and also the involvement of children in parental activities will provide good examples to be able to do activities as well as train them. Parents should instill in their children the understanding that every day they will take a new step in life. In the verse of the Qur'an relating to the nature of a human being is in the letter ar-Rum verse 30 which means i: Meaning: So turn your face straight to the religion of Allah; (stay on) the nature of Allah who has created man according to that nature. there is no change in the nature of Allah. (That is) the straight religion; but most people do not know, (Surah Ar-Rum [30]: 30).

According to some commentators, the word fitrah Allah means the tendency and willingness of humans towards true religion. Because, human nature was created by Allah SWT. to tend to monotheism and din al-Islam so that humans cannot refuse and deny it. Some other commentators such as Mujahid, Qatadah, Ibn Abbas, Abu Hurairah, and Ibn Shihab interpret it with Islam and Tawhid. He interprets nature with Islam because it is for that nature that humans were created (Nikmah, 2017). This is confirmed by Allah in the letter Ad-Dzariyat verse 56 And I did not create the jinn and mankind except that they might serve Me. (Surah Ad-Dzariyat [51]: 56) If you look closely, the two meanings seem to complement each other. And it must be remembered, the word fitrah Allah is positioned as maf'ul bih 
(object) of the hidden fi'il (verb), namely ilzamu (stay) or ittabi'û (follow). That means, humans are commanded to follow the nature of Allah. If so, then the intended fitrah is certainly not enough just to be limited to innate beliefs about God or a tendency to monotheism. Fitrah here must be interpreted as the creed of monotheism or din al-Islam itself. This phrase reinforces the commandment to maintain a total acceptance of Islam, not to lean towards other false religions, and to continue to maintain an istiqamah attitude towards dn al-Islâm, dîn al-haq, which was created by Allah SWT. for humans. This is in line with the word of God in the letter Hud verse 112 which means: So stay on the right path, as you were commanded and (also) those who have repented with you and do not transgress. Verily, He is All-Seer of what you do.. (Surah Hud [11]:112).

Allah SWT. said: Lâ tabdîla li khalqillâh (there is no change in the nature of Allah). According to Ibn Abbas, Ibrahim an-Nakha'i, Said bin Jubair, Mujahid, Ikrimah, Qatadah, adh-Dhahak, and Ibn Zaid, li khalqillah means li dînillâh. The word fitrah is equivalent to the word al-khilqah. If fitrah in this verse is interpreted as Islam or din Allâh, then the word khalq Allâh can also be interpreted as din Allâh. Allah SWT. preach, there is no change for the religion that He created for humans. If Allah swt. does not change his religion, just as humans do not change his religion or replace it with another religion. Therefore, according to some commentators, even though it is in the form of khabar nafî (neglecting news), this sentence gives the meaning of talab nahî (demand to leave). Thus, the phrase can be interpreted: Do not change Allah's creation and religion with polytheism and do not change your original nature by following Satan and his delusions; and return to the religion of nature, namely Islam. The phenomenon that arises at this time is that parents are busy working to improve the economic level of the family, sometimes a little free time to interact with children indicates that the family has lost many of its essential roles and loyalty to children. Because that loyalty has led to other educational institutions that force families to cooperate with them, even to give full responsibility to the school.

On the education side for children who have received new changes from various aspects. Parents, families and schools are no longer the main sources in building and shaping the personality of students. However, education has emerged various kinds of games in entertainment venues, various forms of cartoons and fantasy films on government or private TV and various other technological tools. All of that will be a new virus in the formation of the child's personality. Another thing that adds to the magnitude of the responsibility in preparing the child's personality is the lack of time available for parents to be together with 
their children, because they are busy with work and activities outside the home, children's education is left to helpers. Yet there are differences between the culture of servants and children. This is the problem.

\section{Literature Review}

The Talking about the Position of Parents in the Qur'an, as research launched by (Kharomen, 2019) explained that the expressions that are spread in society regarding children, such as children as gifts, mandates, entrustments, and respond to the rise of problems in society regarding children. children, such as disharmony between children and parents, violence against children or even their parents, lack of parental attention to the fulfillment of children's rights, especially in the right to education and affection. So that in the Qur'an children have various positions, ranging from their position as trials, pride, inclination to love, even as enemies to their parents. This paper also shows that the Qur'an describes the relationship between parents and children in the world in the form of rights and obligations. Children's rights to education, livelihood, and inheritance. As for the rights of parents to get good treatment, love and prayers from their children. In addition, this study also shows that in the hereafter, the relationship between children and parents can be established if it is based on faith and piety.

In terms of Parental Obligations to Children in an Islamic Perspective as research launched by (Fahimah, 2019) it was also mentioned that humans were created by God to worship and worship him, whether it is worship of mahdlah which is directly related to Allah, as well as related to worship of ghairu mahdlah which is related to humans. but in this case it can be intended as social worship. Everything that is done is on the basis of obligations as creatures (created by Allah) who are given the responsibility as leaders (caliphate) on this earth. In order to carry out the responsibility of a leader (caliph) properly and correctly, the tools and tools to carry it out must be present and correct. The tool is in the form of knowledge and expertise. Furthermore, with regard to the obligations of parents to their children, the obligation is none other than preparing children to become a generation that is strong and tough, both physically (physically) and mentally (spiritually). Physically (physically), parents are obliged to provide and prepare food, drink, clothing and shelter. Meanwhile, spiritual (mental) needs, which include identities such as parents, are required to provide the child's name and lineage from the parents. In addition, parents are also obliged to provide education to children, so that children are able to carry out their obligations as servants and are able to protect themselves from the evil of every creature. 
In terms of the concept of parenting in an Islamic perspective on the growth and development of children in the family also what needs to be considered is in being a person entrusted by Allah to take care of children, so feeling that having children is something that is highly expected by a husband and wife. old) in this world. Children can be used as successors to descendants who later can also be heirs to the throne and wealth, and children can also be solace in this life. A child can also be the savior of his parents later in the hereafter and even a child who will put a crown on the head of his parents if in this world they are able to memorize the Qur'an. However, children can also be a barrier for every parent to enter heaven if the child does disobedience while living in the world (Uyuni, 2019). Another thing is about the responsibility of a husband and wife towards children who are sent by Allah, which is related to responsibilities as parents in educating which must prioritize patterns that are not justified in Islam (good and right patterns). So that the phenomenon of mistakes regarding parenting patterns will not be wrong, such as not doing physical and mental violence, being too free, and so on. Parents need to know that their parenting pattern greatly influences changes in their child's behavior or personality. If raised by paying attention to the correct pattern of food intake and educating, it will affect the child's personality to become a pious child. Vice versa, when children are educated with violence, their children will become children who have a crisis of trust, less intelligent (intelligence) and so on. A pious child is the hope of all parents. A pious child is formed by none other than because of the attention of parents on food intake and correct parenting in accordance with Islamic sharia.

Implications of the Role of Parents in Developing the Fitrah of Children in the 4.0 era, which has become a necessity for a husband and wife (parents) in educating children from an early age Islamically, where in this all-digital $4.0 \mathrm{era}$, it is full of challenges that really need to be considered in educating children. properly and correctly according to Islamic sharia. So that in the millennial 4.0 era as it is today, it does not only provide opportunities, but also raises its own challenges for the millennial generation. The closest challenge is to family members, especially parents. In this era, parents are challenged to know and understand how to educate their children properly and correctly. Because different generations have different ways of educating them. The Industrial Revolution 4.0 is marked by the influence of globalization which is mushrooming today, including the easier it is for people to get information from all parts of the world as a result of very rapid technological developments like today. This has positive and negative impacts on children, and it is a shared responsibility for parents to work extra in supervising children, especially in the realm of 
family education. In this case, the role of parents in educating children is very important, in order to guide children so that they have intellectual skills that are in accordance with the times and do not fall into negative things. The steps that parents can take in educating children in the 4.0 era include: 1) Parents must be able to maintain the best possible communication with their children; 2) Parents must be able to know the trends that the child is interested in so that they know how to filter them; 3) Parents must be able to set aside their free time for the sake of the child in order to remain monitored from parental supervision into good things; 4) Parents must be able to be gentle with the child they love; 5) Parents must be able to dig up information about children's activities on a regular basis not to be careless; 6) Parents must be able to provide children with a strong religious education in order to keep bad associations at bay; 7 Parents must always pray for their loved ones to stay safe from bad deeds (Umroh, 2019).

In a digital era like today, there is also a need for massive reforms in the body of Islamic education. Where this reform is needed to maintain the dignity of Islamic education so that it is able to answer the challenges and demands of the times that continue to change from year to year. Therefore, in terms of trying to provide a solution that is a solution to Islamic education in the face of the Industrial Revolution 4.0 Era. As we all know, the 4.0 era has had a broad impact in all walks of life, including education. The era that gave birth to the disruptive phenomenon (4.0) requires the world of Islamic education to adapt to it like a chameleon. Graduates of Islamic education are now faced with new challenges, demands, and needs that have never existed before. So it is necessary to update and innovate the system, governance, curriculum, competence of human resources, facilities and infrastructure, culture, work ethic, and so on. Otherwise, Islamic education will be left behind and obsolete. Therefore, it is necessary to look for real/concrete steps for Islamic education to be able to remain competitive in this era of disruption. The solution is to participate in disrupting oneself in this rapidly developing world (Priatmoko, 2018). Likewise, the role of parents in the 4.0 era today where the urgency of parents in order to be smart parenting when they want to educate their loved ones in the era of the industrial revolution 4.0. In the era of the industrial revolution 4.0, the challenges faced by parents in educating their children are getting tougher (Rumiati et al., 2019). The characteristics of children in this era (disruption) have different characteristics from the previous generation. These differences in characteristics require parents to immediately provide accurate and appropriate parenting strategies in improving the quality of education for their beloved child. So that Smart 
parenting can be used as a parenting strategy for parents who have a smart way of educating their children to achieve optimal development and can solve problems in their child's development. Smart parenting in the 4.0 era is very suitable to be used in educating children in the era of the industrial revolution 4.0 because it can improve the ability of parents in terms of educating superior and intelligent children so that they can optimally support the development of children to become human beings full of hope and ideals.

\section{Research Method}

This research is a qualitative research. The focus is on a comprehensive description of the form, function, and meaning of the expression of prohibition. This is in line with the opinion of Bogdan and Taylor (1975) in (Moleong, 2005, p. 3) which states that qualitative methodology is a research procedure that produces descriptive data in the form of written or spoken words from people and observable behavior. In other words, this research is called qualitative research because it is a research that does not carry out calculations. Qualitative research must consider the qualitative methodology itself. Qualitative methodology is a procedure that produces descriptive data in the form of written or spoken data in the language community. It was further explained that a qualitative approach that uses spoken data of a language requires informants. This approach that involves the language community is directed at the background and the individual concerned holistically as part of a unified whole. Therefore, in language research, the number of informants is not determined. This research method is library research with the object of the verses of the Qur'an using several interpretations from the commentators including: Tafsir Jalalain Tafsir Ibn Kathir Tafsir AlMaraghi to uncover and explore the Position of Parents in the Al-Qur'an, Role Parents in Developing Children's Fitrah, and Implications of the Role of Parents in Developing Children's Fitrah in the 4.0 era (Kharomen, 2019).

\section{Result And Discussion}

\section{The view of Islamic education on the nature of children}

The Qur'an explicitly states that offspring (children) are part of the continuation of the caliphate's mission on earth. That is, the survival of this earth's civilization will depend on the descendants who are the heirs of the previous generation. If they have good qualities, of course life on this earth will continue simultaneously. On the other hand, if it is handed over to an irresponsible generation, then the face of this earth will be colored with chaos and destruction. This is where the urgency of children's education (tarbiyyah al-aulâd) in Islam. 
With a good and sustainable education, children as the next generation and inheritors of life on this earth will become good human beings and are oriented to the benefit. With regard to children's education (tarbiyyah al-aulâd), children have two opposing sides. One side of the child is the trust of Allah entrusted to the parents. On the other hand, children are a slander to the lives of parents in particular and society and the environment in general. Because children are a mandate from God who will be questioned about their accountability, it is the obligation of parents to educate them well so that they become a quality generation. If this trust is wasted, surely the destruction of civilization will soon occur. If it is like this, the child's function as a trust that will continue the continuity of civilization turns into slander. Then what is a good form of education for children so that they become the next generation who are ready to prosper the earth and continue civilization? In this case, the Qur'an and al-Hadith offer many concepts, namely:

1. Islam, through the Qur'an and al-Hadts offers a democratic method of educating children, filled with gentleness and compassion, without forgetting firmness and authority. This is as exemplified by the Prophet Ibrahim as. when he was ordered to slaughter his son, Ismail as. In this incident, Prophet Ibrahim with his democratic attitude consulted with Ismail to ask for his opinion. Finally, with a big soul, Ismail was willing to sacrifice in order to obey Allah's commands. However, the steadfastness and obedience of these two servants of Allah were replaced with a very large reward.

2. Start by choosing a good partner. Quality generation only comes from good and well-maintained seeds. So choosing a partner who has the quality of faith and piety to God becomes very important. Because the color of children's education will depend on the religious commitment of their parents.

3. Pay attention to the stages of children's education. Islam is very observant in the concept of children's education. Among the stages of a child's education include the prenatal stage (before the baby is born), the baby birth stage, the childhood stage, and the adolescent stage.

4. Pay attention to the nature of educators, in this case parents. Because the process of children's education involves three main factors: children as students, parents or teachers as educators, and the environment as a place of education. Among the qualities that parents must possess in educating their children are patient, gentle, compassionate, flexible, moderate, and controlling emotions (Mustaqim, 2005). 
These four basic concepts are the main pillars of children's education in Islam. By paying attention to the four main points above, parents will give birth to a quality and responsible generation that will continue the continuity of this civilization. The role of parents in children's education. The good and bad personality and behavior of children is very dependent on parents. This is as emphasized by the Prophet Muhammad. in a hadith narrated by al-Bukhari: Which means: Every child is born in a state of purity, it is his parents who make him a Jew, Christian, or Magian. (Narrated by Bukhari). So the role of parents in the education of their children is very important. Because this is concerned with the future of children and the future of civilization. In educating children there are several factors that need to be considered by parents. First, the attitude of love. This attitude is important for parents to apply in educating their children, because this attitude will create a peaceful atmosphere in the effort to develop children's mentality. But parents must distinguish the attitude of affection with an attitude of pampering. Sometimes parents think that loving children is by pampering them. Precisely by pampering children, it will give birth to a soft mentality and an independent attitude in children. Second, wise attitude. Besides being determined by the love factor in the family, the success of the child's education process is also largely determined by the wise attitude of parents in educating their children. This was exemplified by the Prophet Muhammad. when he educates generations of friends with a wise attitude that is contained in the values of exemplary, justice, honesty, and responsibility. So that gave birth to friends who colored civilization with glory and brilliance. Third, effective communication in the family environment. Communication in the family, which is built on the foundation of love, becomes important in educating children, because it is a means of passing on moral values from parents to children. Sometimes parents do not have the time and means to communicate with their children because of busy work. Yet this is where the door to failure in educating children. Fourth, create a harmonious family. This point becomes very urgent, because it is from a harmonious family environment that a child with a positive mentality will be born. While children who are raised in families that are not harmonious will suffer from personality development disorders. These four main factors are the responsibility of parents in their implementation efforts. So that the main role of parents in realizing the four factors above in domestic life is the gateway to realizing good children's education, as a starting point for creating a quality generation.

By nature, children need education or guidance from adults. This natural basis can be understood from the basic needs possessed by every child who lives in this world. Children 
are the mandate of Allah Subhanahu Wata'ala to us, each of us hopes his children to be good children, and therefore it is necessary to optimize the responsibilities and roles of parents. Although basically a child is born on fitrah, but this does not mean we leave him without good and directed direction and guidance, because something that is good if it is not cared for and cared for will become bad due to the influence of external factors. Good education and direction for children actually have to start since the child has not been born even before the child is in the womb. From this it can be understood that humans with all their character and growth are the result of the achievement of two factors, namely inheritance factors and environmental factors. These factors influence humans in interacting with them since they become embryos until the end of life. Then, a comfortable and supportive environment for the implementation of an education is needed and also influences the achievement of the desired educational goals. Likewise in the Islamic education system, the environment must be created in such a way according to the characteristics of Islamic education itself. Although the environment is not responsible for the maturity of students, the environment is a very decisive factor and has a very large influence on students. Because, however a child lives in an environment, consciously or not, the environment will affect the child. This shows that Islam recognizes the potential of the environment whose influence can be very strong so that it is very possible to defeat nature. Thus it can be concluded that the educational environment plays an important role in the implementation of Islamic education. This is because the environment, also known as the institution, is the place where the educational process takes place, which in general can be seen from three things, namely family, school, and community. The formation of the family is very necessary so that he is able to educate his children according to the principles of Islamic teachings. Then, parents must realize the importance of schools in educating their children professionally so that parents must also choose good schools and participate in improving the school.

Meanwhile, schools or madrasas also play an important role in the educational process. Schools as formal educational institutions, which are essentially institutions that carry the mandate of parents and society, must provide professional education in accordance with the principles and characteristics of Islamic education. Schools must teach various knowledge and skills to their students according to the abilities of the students themselves. So children can be a pleasant dream, when educated well, and vice versa will be disastrous if not educated. This is the possibility that arises, namely a sense of optimism or pessimism. This also leads to an understanding of what it means to take care of children, if they are not 
educated, students doing evil are the fault of the educator, and if the children do not want to learn, it will only make it difficult for their parents, homeland and nation. It is clear that children must be educated, because in essence humans are born with a nature that can be educated, can educate and at the same time be able to educate and be educated.

\section{Mufassir's View About Surah Ar-Rum Verse 30}

1. Text and Translation



So turn your face straight to the religion of Allah; (stay on) the nature of Allah who has created man according to that nature. there is no change in the nature of Allah. (That is) the straight religion; but most people do not know (Surah Rum [30]: 30).

2. Meaning of Mufrodat

\begin{tabular}{|c|c|c|c|}
\hline $\begin{array}{l}\text { What is meant is the } \\
\text { nature that has been } \\
\text { mentioned earlier }\end{array}$ & خَلْقِ اللَّهِ & 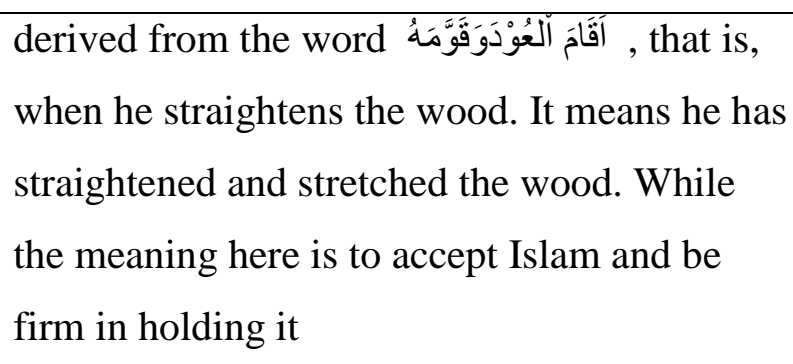 & أَقِقٌْ \\
\hline $\begin{array}{l}\text { straight with no } \\
\text { bends and } \\
\text { deviations }\end{array}$ & 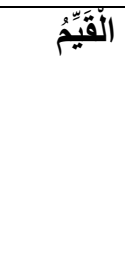 & $\begin{array}{l}\text { comes from the word al-hanif which means } \\
\text { God can be investigated in humans, namely } \\
\text { willing to accept the truth and preparation to } \\
\text { find it. }\end{array}$ & حَنِيفاً \\
\hline
\end{tabular}

\section{Interpretation}

TaInterpretation Tafsir Jalallain (Muhammad Jalaluddin as-Suyuthi) explained that (So face) O Muhammad (your face straight to the religion of Allah) means to incline yourself to Allah's religion, that is by being sincere with yourself and those who follow you in practicing His religion (nature of Allah) His creation (who has created humans according to that nature) namely His religion. The meaning in question is, stay on the nature or religion of Allah. (There is no change in Allah's nature) in His religion. That means do not replace it, for example associating partners with Him. (That is the straight religion) The religion of 
monotheism is the straight religion (but most people) i.e. the disbelievers of Mecca (do not know) the monotheism or the oneness of Allah (Sututhi, 2004, p. 347).

Tafsir Ibn Katsir (Muhammad Abu Fida Ibn Katsir) explains that Allah SWT. said: Fa aqim wajhaka li ad-dîn hanîfâ (Keep your face straight to the religion of Allah). According to Mujahid, Ikrimah, al-Jazairi, Ibn al-'Athiyah, Abu al-Qasim al-Kalbi, and az-Zuhayli, the word ad-dîn means din al-Islam. This interpretation is very precise, because the khithab of this verse is addressed to the Messenger of Allah, of course the religion in question is Islam (Katsir, 2007, p. 441). As for hanif, it means tending to the straight path and leaving astray. The word hanif is a hâl (description) for adh-dhamîr (pronoun) from the word aqim or the word al-wajh; could also be a matter for the word ad-dn. Thus, the commandment requires to turn the face to dn al-Islam with a straight gaze; do not turn to the left or the right, and do not incline to other false and deviant religions. This command is an image to describe the attitude of total acceptance of this religion, istiqamah in it, steadfast in it, and views it as very important. said: fitrah Allâh al-latî fathara an-nâs 'alayhâ (stay on the nature of God who has created humans according to that nature). Linguistically, fitrah means al-khilqah (instinct, nature) and ath-thabî'ah (character, character) created by Allah SWT. in humans.

According to some commentators, the word fitrah Allah means the tendency and willingness of humans towards true religion. Because, human nature was created by Allah SWT. to tend to monotheism and din al-Islam so that humans cannot refuse and deny it. Some other commentators such as Mujahid, Qatadah, Ibn Abbas, Abu Hurairah, and Ibn Shihab interpret it with Islam and Tawhid. He interpreted fitrah with Islam because it was for that nature that humans were created. It has been confirmed that the jinn and humans were created by Allah. to worship Him as Allah has explained in the letter ad-Dzariyat verse 56 which means and I did not create the jinn and humans except that they serve Me. (Surah adzDzariyat [51]: 56). If you look closely, the two meanings seem to complement each other. And it must be remembered, the word fithrah Allah has the position as maf'ûl bih (object) of the hidden fi'il (verb), namely ilzamû (stay) or ittabi'û (follow). That means, humans are commanded to follow the nature of Allah. If so, then the intended fitrah is certainly not enough just to be limited to innate beliefs about God or a tendency to monotheism. Fitrah here must be interpreted as the creed of monotheism or dn al-Islam itself. This phrase reinforces the commandment to maintain a total acceptance of Islam, not to lean towards other false religions, and to continue to maintain an istiqamah attitude towards dn al-Islâm, dîn al-haq, which was created by Allah SWT. for humans. This is the same as the word of 
Allah in Surah Hud verse 112 which means: So stay on the right path, as you were commanded and (also) those who have repented with you and do not transgress. Verily, He is All-Seer of what you do. (Surat Hud [11]:112).

Allah SWT. said: Lâ tabdîla li khalqillâh (there is no change in the nature of Allah). According to Ibn Abbas, Ibrahim an-Nakha'i, Said bin Jubair, Mujahid, Ikrimah, Qatadah, adh-Dhahak, and Ibn Zaid, li khalqillâh means li dînillah. The word fitrah is equivalent to the word al-khilqah. If fitrah in this verse is interpreted as Islam or din Allâh, then the word khalq Allâh can also be interpreted as din Allâh. Allah SWT. preach, there is no change for the religion that He created for humans. If Allah SWT. does not change his religion, just as humans do not change his religion or replace it with another religion. Therefore, according to some commentators, even though it is in the form of khabar nafî (neglecting news), this sentence gives the meaning of talab nahî (demand to leave). Thus, the phrase can be interpreted: Do not change Allah's creation and religion with polytheism and do not change your original nature by following Satan and his delusions; and return to the religion of nature, namely Islam.

Allah SWT. Closing this verse with His words: Dzâlika ad-dîn al-qayyim walâkinna aktsara an-nâs lâ ya'lamûn (That is the straight religion, but most people do not know). The word al-qayyum is a mubâlaghah form of the word al-qiyum (straight). Allah SWT. emphasized that the command to follow the religion of monotheism and adhere to sharia and a healthy fitrah is a straight religion; there is no crookedness and deviation in it. The Meaning of Fitrah The Salaf scholars differ in the meaning of the word fitrah with quite a lot of opinions. The most famous opinion in this regard is that it means Islam. Ibn Abdil Bar said: "This opinion is known among the Salaf scholars." The scholars also agree in interpreting the meaning of fitrah in the verse: which means "(Stay on) the nature of Allah who has created man according to that nature." (Surat Ar-Rum, [30]:30).

Tafsir Al-Maraghi (Mustafa al Maraghi) explains that then direct your face straight towards the direction that has been determined by your Lord to obey Him, namely the direction of the straight religion and the religion of nature. And turn away from misguidance towards guidance. اللَّهِ التَّي النَّاسَ لَيْهَا Keep all of you in the nature that Allah has created in human beings, because indeed he has created in them a nature that always tends to the teachings of monotheism and convinces it. The thing that guided him to his sound mind. עل It is not worthy of Allah's nature to be replaced or changed. This is a news sentence that contains the meaning of a command so it is as if it is said, "Do not replace the religion of 
Allah with polytheism." The explanation is that the human mind is like a clean white sheet and is ready to accept the writing that will be poured on it, and it is like a field that can accept everything that will be instilled in it. He can grow hanzal (whose fruit is very bitter) just as he can grow all kinds of fruiting trees and he can grow medicine and poison. The human soul comes to him various religions and knowledge, then he absorbs it but it is the good things that he absorbs the most (Maraghi, 2001, p. 271).

Like plants, most of them contain poison and very little is not useful. And the human soul will not replace this good nature with corrupted opinions unless there is a teacher who teaches it. That is like two Jews and Christians. If parents let their children, surely the child will know by itself, that God is one and his mind will not guide him. For verily even cattle will not have their ears or other body parts cut off except for factors from outside themselves. Likewise, the sheet of reason, he will not be affected but from external factors that are

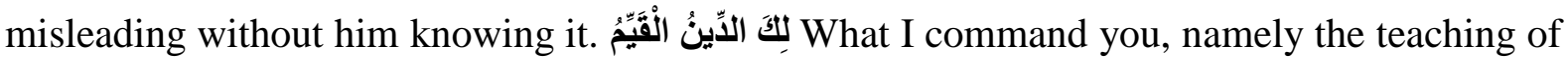
monotheism, it is a true religion, there is no crookedness and no deviation in it. لَكنَّ النَّاس لائِ كَئون But most people don't know, that's because they don't want to use their minds to think about clear evidences that point to this monotheism. Had they known the truth, they would have followed it, and they would not have prevented humans from absorbing His light. And surely they will not lower the barriers that prevent the entry of the rays of monotheism into human beings

\section{Conclusion}

The conclusions of this paper are as follows: 1) The view of Islamic education about the nature of children, the position of children has two opposing sides. One side of the child is the trust of Allah entrusted to the parents. On the other hand, children are a slander for the lives of parents in particular and society and the environment in general. Because children are a mandate from God who will be questioned about their accountability, it is the obligation of parents to educate them well so that they become a quality generation. If this trust is wasted, surely the destruction of civilization will soon occur. If it is like this, the child's function as a trust that will continue the continuity of civilization turns into nature. 2) The implications of the position of parents in developing children's nature, the implications of which in the 4.0 era are a necessity as the mufassir's view of the letter ar-Rum verse 30 is Allah SWT, proclaiming, there is no change for the religion He created for humans. If Allah SWT does not change his religion, humans should not change his religion or replace it with another religion. Fitrah as the opinion of the Salaf scholars differ in the meaning of the word fitrah 
with quite a lot of opinions. The most famous opinion in this regard is that it means Islam. Fitrah Salaf scholars differ in the meaning of the word fitrah with quite a lot of opinions. The most famous opinion in this regard is that it means Islam. So that it has become a joint obligation for parents to maintain the mandate of Allah SWT in the form of children, which in the 4.0 era children must be monitored and supervised to ensure that the child's behavior (behavior) as a child who was born naturally (good) in origin.

\section{References}

Alim, M. (2006). Pendidikan Agama Islam. Bandung: Rosda Karya.

Dariyo, A. (2013). Dasar-dasar Paedagogi Modern. Jakarta: Indeks.

Fahimah, I. (2019). Kewajiban Orang Tua terhadap Anak dalam Perspektif Islam. Jurnal Hawa: Studi Pengarus Utamaan Gender Dan Anak, 1(1), Article 1. https://doi.org/10.29300/hawapsga.v1i1.2228

Gunawan, H. (2012). Kurikulum dan Pembelajaran Pendidikan Agama Islam. Bandung: Alfabet.

Katsir, I. I. (2007). Tafsir Ibn Katsir. Beirut: Dar el Fikr.

Kharomen, A. I. (2019). Kedudukan Anak dan Relasinya dengan Orang Tua Perspektif AlQur'an. Andragogi: Jurnal Diklat Teknis Pendidikan dan Keagamaan, 7(2), 199214. https://doi.org/10.36052/andragogi.v7i2.88

Maraghi, I. A. (2001). Tafsir al Maraghi. Beirut: Dar el Fikr.

Moleong, L. J. (2005). Metodelogi Penelitian Kualitatif (20th ed.). Remaja Rosdakarya.

Mustaqim, A. (2005). Menjadi Orangtua Bijak, Solusi Kreatif Menangani Pelbagai Masalah Pada Anak. Bandung: Al-Bayan Mizan.

Nikmah, L. (2017). Penafsiran Ṭāhir Ibn 'Āsyūr Terhadap Ayat-ayat tentang Demokrasi: Kajian atas Tafsir al-Taḥīr wa al-Tanwīr. Journal of Islamic Studies and Humanities, 2(1), 79-103. https://doi.org/10.21580/jish.21.2517

Priatmoko, S. (2018). Memperkuat Eksistensi Pendidikan Islam Di Era 4.0. TA 'LIM : Jurnal Studi Pendidikan Islam, 1(2), 221-239.

Rumiati, R., Purbayani, S. F., Irmawati, T., \& Hidayah, R. (2019). Urgency of Parents as Smart Parenting Against Child Education in The Industrial Revolution Era 4.0. Social, Humanities, and Educational Studies (SHEs): Conference Series, 2(1), 376381. https://doi.org/10.20961/shes.v2i1.38436

Sututhi, I. L. as-. (2004). Tafsir Jalalain. Beirut: Dar el Fikr.

Syaibany, O. A.-T. A.-. (1979). Falsafah Pendidikan Islam. Jakarta: Bulan-Bintang. 
Umroh, I. L. (2019). Peran orang tua dalam mendidik anak sejak dini secara islami di era milenial 4.0. Ta'lim : Jurnal Studi Pendidikan Islam, 2(2), 208-225.

Uyuni, Y. R. (2019). Konsep pola asuh orang tua dalam perspektif islam terhadap tumbuh kembang anak dalam keluarga. As-Sibyan: Jurnal Pendidikan Anak Usia Dini, 4(1), 53-62. https://doi.org/10.32678/as-sibyan.v4i1.1964 
Agus Yosep Abduloh, dkk

170 Volume 7 No. 2 , 1 September 2021 